\title{
Public Relations in Environmental Education: An Example Practice from Turkey
}

\author{
Elif Sesen \\ T.R. Ministry of Environment and Forestry \\ NRCC of EEA (National Reference Center for Communication of European \\ Environment Agency) \\ Beştepe Mahallesi Alparslan Türkeş Caddesi No: 71 - Yenimahalle / Ankara, Turkey \\ Tel: 90-544-232-1514 E-mail: elifsesen@gmail.com
}

Received: April 6, 2015 Accepted: April 22, 2015 Published: April 23, 2015

doi:10.5296/jsss.v2i2.7392 URL: http://dx.doi.org/10.5296/jsss.v2i2.7392

\begin{abstract}
In recent times, environmental sensitivity and awareness is rising rapidly. Environmental Education (EE) is so important to protect the environment and leave it healthy to next generations. But it is not a subject that can be solved only by laws and rules. It needs to support of public and Public Relations (PR) activities may be a useful way for this. In different countries, lots of PR campaigns have been held on environment. In this study, an example practice from Turkey on environmental education is presented.
\end{abstract}

Keywords: Environmental education, Public relations

\section{Introduction}

Environment is becoming a crucial topic that is given more importance by public and also governments day by day. While environmental resources are reducing, needs of the people are increasing continuously. One of these needs is living in a healthy environment. But a healthy environment is a complex subject that has a lot of dimensions like economic, social, cultural, educational, etc. Because it is difficult to balance demands with the environmental resources.

In Turkey, environmental protection and environmental education are becoming important requirements. Although number of non-governmental organizations related to the environment increased environmental protection and also environmental education are considered as the task of the state. 
Environmental Education (EE) is vital to protect the environment and first responsibility of the public corporations like ministries and schools. Governmental organizations make regulations and put rules on the environment but their responsibilities are not limited by legislations, since environment and environmental education is not a subject that can be solved only by laws and rules. By this mean, EE needs the support of public and Public Relations (PR) activities may be a useful way for this help.

It is not enough only to use technology and laws for solving environmental problems. In order to deal with environmental problems and generate solutions, it is necessary that the individual be educated, sensitive and aware. Change towards a better quality of life starts with education.

Thus, the purpose of this study is to demonstrate the importance of EE for adults and role of $\mathrm{PR}$ activities in EE on a sample project.

\section{Environmental Education}

Environmental problems are increasing for reasons such as rapid population growth, industrialization, and urbanization have reached international levels. The interaction between man and the environment is indispensable and today environment has different dimensions. Living in a healthy and balanced environment is a human right. There are international and national legislation to protect this right. But making the legislation on issues related to the environment is not enough; success is only possible with social persuasion, support and education.

Environmental education refers to organized efforts to teach about how natural environments function and, particularly, how human beings can manage their behavior and ecosystems in order to live sustainably (Smyth, 2006). It has crossover with multiple other disciplines.

According to Lieberman and Hoody (1998), EE is the teaching of individuals, and communities, in transitioning to a society that is knowledgeable of the environment and its associated problems, aware of the solutions to these problems, and motivated to solve them.

It is generally used to imply education within the school system; however, it is also used more broadly to include all efforts to educate the public and other audiences, including print materials, websites, media and public relations campaigns, etc. In this study, the term is used in broader meaning.

Environmental education focuses on (Bamberg \& Moeser, 2007; Wals et al., 2014):

- Engaging with citizens of all demographics,

- Think critically, ethically, and creatively when evaluating environmental issues;

- Make educated judgments about those environmental issues,

- Develop skills and a commitment to act independently and collectively to sustain and enhance the environment, 
- To enhance their appreciation of the environment; resulting in positive environmental behavioural change.

The roots of environmental education can be traced back as early as the 18th century when Jean-Jacques Rousseau stressed the importance of an education that focuses on the environment in Emile: or, On Education (Palmer, 1998). The modern environmental education movement gained significant momentum in the late 1960s and early 1970s. It was born of the realization that solving complex local and global problems cannot be accomplished by politicians and experts alone, but requires "the support and active participation of an informed public in their various roles as consumers, voters, employers, and business and community leaders." (Kyburz-Graber et al., 2006).

Internationally, environmental education gained recognition when the United Nations Conference on the Human Environment held in Stockholm, Sweden, in 1972, declared environmental education must be used as a tool to address global environmental problems. The United Nations Education Scientific and Cultural Organization (UNESCO) and United Nations Environment Program (UNEP) created three major declarations that have guided the course of environmental education as Stockholm Declaration (1972), Belgrade Charter (1975) and Tbilisi Declaration (1977). These documents are guidelines for EE in schools especially.

Environmental education gained a global dimension with the Stockholm Conference on Human Environment. The Conference Declaration "humanity, protect the environment for present and future generations and is obliged to improve". In the words carefully, was drawn to the faces of the people's environmental attitudes and behaviors.

International Environmental Education Programme (IEEP) came to life in 1975 in collaboration with UNESCO and the United Nations Environment Programme (UNEP).

The 1977 Tbilisi Conference created a landmark beginning for international environmental education. In the light of the decisions taken at the Tbilisi Conference through the environmental education "to reach the environment and aware of environmental issues and awareness raising, providing information about the environment and environmental issues, ensure the development of positive and realistic attitudes about the environment, improving the necessary motivation to develop and protect the environment" are intended.

Three approaches to environmental education are mentioned (Huckle, 1993):

1. Training for environmental management and control: According to this approach, EE encourages the learning about physical and human systems and also interaction of these systems.

2. Education for environmental awareness: According to this approach, EE allows students to gain a variety of skills about environment.

3. Education for sustainability: According to this approach, EE encourages students to be responsible for their own behaviors.

Popularity of EE is increasing and it is becoming a subject that more emphasized in schools. 
However, it is not possible to say that the point we reached is enough.

Traditional education has a role of transmitting existing knowledge of society to individuals and also has to promote young people's competencies for critically analyzing and reflecting the environment awareness. The individuals should learn the causes of these problems and how to avoid them. School related EE policies focus on three main components: curricula, green facilities, and training. However EE is not restricted to in-class lesson plans. There are numerous ways children can learn about the environment in which they live. One of these ways is outdoor education. Outdoor education in EE relies on the assumption that learning experiences outdoors in 'nature' foster an appreciation of nature, resulting in pro-environmental awareness and action (Clarke \& Mcphie, 2014).

Achieving the goals of EE requires widespread community education. The studies have shown that increasing individual' environmental knowledge may results in more positive attitudes and more responsible environmental behaviors. According to Hines et al. (1986), responsible environmental behaviors are learned actions including understanding the ecological principles and processes. This may include interrelationship between social and natural systems. Environmental behaviors of individuals' mostly reflect their environmental knowledge that this means responsible environmental behaviors (Roth, 1992; Wilke, 1995).

But it is also known that environmental education growth does not always affect environmental attitudes in positive direction. It is generally accepted that complex issues of basic knowledge do not necessarily have effect on the individuals' growing responsible attitudes towards environment (Hungerford \& Volk, 1990). To educate communities about environment, it is important that we should change and modify their lifestyle and make them aware of new things. Public relations (PR) may be a useful way for EE.

\section{Public Relations (PR) in Social Issues}

It is hard to define the concept of public relations in a particular framing. It is difficult to arrive at a common definition on PR because it has a wide application field and to be implemented with different objectives in public and private organizations.

According to Edward Bernays (1928), the public relations counsel is the agent working with both modern media of communications and group formations of society in order to provide ideas to the public's consciousness.

Grunig and Hunt (1984) defined PR as a practice of managing the spread of information between an individual or an organization (such as a business, government agency, or a nonprofit organization) and the public.

McCamy (1940) gave a definition from public sphere and according to him PR is direct or indirect contacts between citizens and the state mechanism in the public sphere.

In 1982, Public Relations Society of America (PRSA), a professional trade association, defined public relations as "PR helps an organization and its publics adapt mutually to each other." (Lattimore et al., 2004). In 2012 the PRSA developed a crowd-sourced definition as PR can also be defined as the "practice of managing communication between an organization 
and its publics."

In short, PR may be defined as the establishment of a two-way communication system in a planned manner by the purpose of gaining the community understanding and support.

The aim of public relations is to inform the public, prospective customers, investors, partners, employees, and other stakeholders and ultimately persuade them to maintain a certain view about the organization, its leadership, products, or of political decisions (Seitel, 2007).

In other words, purpose of public relations is to impress the audience and to embark them on a certain belief and action.

According to Pieczka (2006) communication system created by public relations is based on the exchanging messages and includes development of dialogue and arguments about public problems. PR may provide a mechanism for the public opinion by these ongoing public debates.

To win the support and trust of the community is vital for the public sector. Public relations activities contribute to adopting public policies and institutional decisions and gaining support of the public. It is so important in social issues and social problems like environment.

\section{Environmental Education in Turkey}

Turkey is a country which has the high rate of population growth which is a typical characteristic of developing countries and lifestyles. The consumption pattern, economic and industrial development is characteristic that make environmental education critical as a tool for achieving sustainable development.

In Turkey, while there were numerous publications on environmental issues, it is not possible to say the same thing in the field of environmental education. Especially in recent years an increasing trend may be mentioned.

Environment Act No 2872 came into force in 1983 in Turkey. The purpose of the Act is to ensure protection of the environment in line with sustainable development and environment principles. The law contains provisions relating to the conservation and protection of wetlands and biodiversity. There are no any regulations on it related to environmental education.

In the National Environmental Strategy and Action Plan (NEAP) which has an important place in environmental policy, it is written that "education for environment is one of the prior actions". Despite the expressed commitment on the issue, in practice it is not current situation.

Priorities of the national environmental programs are consistent with EU environmental policy. But success of the program will depend on an effective and conscious environmental education, since the most basic way to deal with environmental problems is through conscious and organized education of all individuals in society.

Developments in environmental legislation were recorded in Turkey on different topics such 
as solid waste disposal, wastewater treatment, watershed protection, air quality. Yet public awareness is not at the desired level. Human is the first factor to damage the environment but is the most important to protect it too. For this reason, environmental education is the most important element of environmental protection.

If we construct a simple model which we resemble the environmental protection to a building, legislations will be the foundation of the building. Activities and projects will create the body of the building and roof will consists of environmental education. EE will contribute to ensure correct understanding of enacted laws and regulations and also organize useful and right projects.

In Turkey, students' environmental education starts with the Life Science in primary school. And with some parts such as science, chemistry and biology this education continues in university.

In the past, EE was given as a separate subject under the name of "Environment and Human" at 9th class and then this lesson was removed from curriculum and environmental issues started to be taught in biology (Ozdemir, 2007). Despite the increased popularity of environmental content in schools, environmental studies are not mandatory in universities and secondary school curriculum. Therefore, the majority of pupils are not receiving the long-term, continuous, methodical exposure to the subject that is necessary for developing substantial environmental literacy (Goldman et al., 2003).

Teacher training programs of education faculties have been modified according to currently environmental issues. It may be a good beginning point but it is not enough.

A study carried out by Bahar (2000) has demonstrated that many college students have the wrong information or never informed about the depletion of the ozone layer or the greenhouse effect before taking "Environmental Science" course. Some of these students have taken "Environment and Human" lesson in high schools.

Unfortunately, faculty of education students who would train the children has not enough information about environment too. In a study implemented in Konya Selçuk University Faculty of Education, some key environmental terms such as "acid rain", "ecology", "recycling", "greenhouse gases" have been given to the students and were asked to tell a sentence about them but $28 \%$ of the students did not write any description about acid rain, and $74 \%$ recycling, $35 \%$ the greenhouse gases. So candidate EE teachers need environmental education (Oztas\&Kalipci,2009). The findings of this research also have shown that enormous amount of teacher candidates $(68 \%)$ has not attended in any environmental meeting, symposium or other activities.

Hausbeck, Milbrath and Enright (1992) showed that primary school students (63\%) have environmental information mostly from the media. They have learned from the school of $12 \%$ and $9 \%$ from the family and friends. These results demonstrate that information gained from family or mass media is as important as teaching in schools.

From this point, it is important that planning and organizing PR activities which will 
contribute to benefit from media in the environmental education.

\section{An Institutional PR Practice: Mobile Environmental Education Vehicles (MEEV) Project}

The main objectives of public relations in public administration are enlightening of the public about the issues in their responsibility area, facilitating the public's processing and explaining the laws and rules.

In Turkey, Ministry of Environment and Forestry (Ministry of Forestry and Water Affairs since 2011) is responsible of conservation of water, land and forest resources. One of the main tasks of the ministry is environmental education.

Ministry held a PR campaign to give information about water conservation, importance of reforestation and prevention of forest fires to the public generally. Project name was

Mobile Environmental Education Vehicles (MEEV).

Cutlip and Center (1955) give stages of a PR process as:

- Data Collection

- Planning

- Implementation

- Review

They state that data collection is important to find out and understand the people who your target groups.

Planning is to determine how to use the information collected. Plans may be short, medium or long term. At this stage; main objectives, communication strategy, message contents and channels for the messages are designated. In the messages there are four basic components as sender (source), message, channel and receiver.

At the implementation stage, designated messages are transmitted by written and oral common symbols, planned activities are achieved. At the last stage, a review is made to evaluate the results of the performed project for the next campaigns. In MEEV Project, this process was followed. For the project five special vehicles designed for EE and the vehicles traveled the whole country in all 81 cities in seven months.

\subsection{Data Collection}

Environmental Status Report (2010) has been prepared by T.R. Ministry of Environment and Forestry per year on a regular basis in order to demonstrate the country's environmental indicators. Reports show that in Turkey the main cause of environmental problems is unconscious behaviours of people. For example in Turkey, 93\% of forest fires are human based (Forest Fires Fighting Action Plan, 2012). Besides, Turkey is a country facing water scarcity according to $1.735 \mathrm{~m}^{3}$ of water available per capita (Varınca, 2008:31) and water conservation is essential. So EE is a basic need to prevent environmental problems caused by people in Turkey.

It is a need to attract the attention of people who are subject to both the victim and the 
perpetrator of the environmental pollution. EE is important to understanding of the people that conservation of the environment actually means to protect their own lives. MEEV Project is scheduled to be one step closer to this goal.

\subsection{Planning}

In February 2010, an investigation was launched for the available resources for the design of vehicles. A draft task sharing was made between the directorates of the Ministry of Environment and Forestry and issues such as accommodation, renovation of the vehicles were distributed. Directorates also were asked to prepare printed and visual materials about their areas.

Then video conferences were performed with the 81 regional offices of general directorates of the ministry and in the visual meeting project details were explained to the administrators. They were asked to define suitable places for the accommodation of the vehicles in their provinces and to prepare list of the schools for the plays of Squirrel Children's Theater by contacting the Provincial Directorate of Education. Administrators were also asked to make a draft activity program.

Simultaneously, a web site (www.cevreormanegitimi.cob.gov.tr) for the project was made to reach more people by digital media. Meetings were held with the non-governmental organizations (NGOs) for support.

Plans were revised for the third part of the project. Cooperation with the Ministry of Education teachers for school training was determined. Draft education program was prepared and team of trainer was chosen among the employees of the Ministry. It was planned to give training to at least 300 teachers during one week as two sessions in a day and including 30 teachers per session.

In planning stage, target groups, timing, stakeholders and objectives were determined.

\subsubsection{Target Groups}

Premier target group of the project was children in environmental education, since the early age education is more effective.

Target audiences identified for the first period of Mobile Environmental Education Vehicles (MEEV) Project were:

- Students in the elementary level

- Local government representatives

- Local media

- People living in city centers

Target groups identified for the 2nd phase of the project were:

- People living in areas where intensive in forest fires

- People living in the provinces selected as pilot provinces and districts

Target audience specified for the third period of the project was:

- Primary school teachers in public schools

- Students of education, forestry and civil engineering faculties 


\subsubsection{Timing}

MEEV was planned as 3 periods between April-October 2010:

First Period (April-June 2010): Target group was students. Outdoor activities are planned for spring months which have more suitable weather conditions. First period ending date was defined as the end of the academic year.

Second Period (July 2010): Target group was people who lived in place intensive forest fires. Summer months were preferred because of the possible forest fire season.

Third Period (September-October 2010): Target group was teachers in primary schools. Last period beginning date was defined as the beginning of the academic year.

\subsubsection{Stakeholders}

Stakeholders of the project were:

- Ministry of Education

- Local administrators

- Local media

- Municipalities

- Non-governmental organizations

- Recycling companies

- Citizens

- Students

- Teachers

\subsubsection{Objectives}

Main objectives of the project are increasing environmental awareness of all citizens, particularly to children and also introducing the basic environmental concepts such as "recycling, carbon footprint, waste, and etc."

Other objectives of the project were:

- Adopting and raising awareness' of the people especially students about basic environmental concepts such as "recycling, waste, carbon footprint",

- Increasing the awareness and support of local government representatives,

- Drawing attention of the people and local media to the local environmental problems,

- Increasing the support for the reduction of human-induced forest fires,

- Making the guidance of environmental education for the students to teachers,

- Creating the database of the volunteers who want to get involved in environmental conservation activities in their provinces.

\subsubsection{Tools}

Tools which are for the activities and events to achieve the objectives of the project are identified on two levels as Employees and Materials \& Equipment.

Employees: Two groups of staff were formed, "vehicle staff" to travel by the trucks and "project staff" to provide information among the employees of the Ministry of Environment and Forestry. Two day trainings were given about vehicle specifications, itinerary, draft 
program of activities of each province to the chosen car responsible person. Also project staff took training about the project and had been asked to make preparations environmental resources and problems in their regions. Demonstrations and competitions on the platforms of the vehicles were planned and 10 animation teams were created within the scope of the province programs. Animation teams had training on basic environmental concepts too.

Materials \& Equipment: Some printed materials and seedlings were prepared to distribute during the events. Seedlings were obtained from plantations of the ministry. Also a project website was made to share the progress of the project. Platform for the Separate Collection of Waste at Source (AKAT), one of the supporter NGOs, provided informative brochures and waste battery boxes for each vehicle.

\subsubsection{Communication Strategy}

The communication strategy of the project was based on face to face communication. Way of giving information in place to the people is chosen in order to increase the awareness about water resources, protected or endemic species in the area inhabited. Little teams are organized by specialists who are from general directorates such as General Directorate of State Hydraulic Works, General Directorate of Forestry and General Directorate of Meteorology to give information to the visitors continuously.

\subsubsection{Key Messages}

The main messages of the project are summarized in the project slogan: "We share the same water, same soil, same air, and same world."

It had been underlined that pollution was a problem that affects all the people and environmental protection was joint responsibility of everyone.

\subsubsection{Channels}

The project mainly focuses on the local media. Local media is as strong as the national media that had more information about the regional problems. Local media have to be informed fully and right to be able to transfer the accurate information to the citizens. At planning stage of the project, local media were investigated in all provinces. Before the arrivals of the vehicles to every city, press releases and announcements were made to the local media and also environmental investments brochures prepared for each province were sent electronically.

\subsection{Implementation}

Vehicles hit the road in designated routes on 22nd of April 2010 after all the tools and materials provided. At first period of the project went on until 18th of June 2010. During the time vehicles visited all 81 cities and 136 towns. Five vehicles toured $24.950 \mathrm{~km}$ in 57 days.

In all cities under the project, Squirrel Children's Theatre show was exhibited at least in three primary schools. On the vehicle platforms animations and small prize competitions were performed with the children.

Visitors filled the "Volunteer Forms" if they wanted and so a database had been created with the e-mails and contact information of the volunteers.

Another slogan of the project was "Do not throw, bring us". During the process hundreds of waste batteries were collected in the waste battery collection boxes and then they were 
delivered to AKAT.

There were machines on the vehicles to measure "Carbon Footprint" to show the effects on the environment of the person's activities.

During the first period vehicles were monitored 24 hours via GPS system and activities were shared on web site.

Second period was performed between 1-31st of July 2010. Cities on the Mediterranean Sea were chosen especially to draw attention to forest fires. In this period visitors were informed about forest fires, precautions which could be taken against them and biodiversity of forests. Trucks were accompanied by a Fire Fighting Vehicle. Cooperation with three universities designated planting and spring festivals were held.

Last period of MEEV Project was between 1st of September and 31st of October 2010 in 16 metropolitan municipalities. EE was given to chosen primary school teachers within the municipality borders. During one week a total of 3,439 teachers were given Applied Environmental Education main goal of which was to give basic information about environment and to introduce the teachers to meet with different training techniques in EE. In the trainings teachers were asked to fill a questionnaire consists of a few questions for the purpose of learning the interest level on environmental issues of them. Questions were about their former EE experiences, their ideas about the most important environmental problems and etc. Training program was consisting of a short informing and then interactive games. There were plays which aimed to explain the water movement in a basin of water such as blue planet, drop bucket, $\mathrm{H}_{2}$ Olympics, sum of the parts, incredible journey among the games.

5.4 Review

More than 5 million people visited the vehicles during the first two periods. Drawing attention of the local authorities was a significant achievement of MEEV Project. During the programs 77 governors, a lot of mayors and local administrators visited the vehicles.

Vehicles reached the people where they live, worked in rural and urban areas.

At the end of the project,

- Distributed total of 400,000 informative brochures to the visitors.

- Collected nearly half a million used battery,

- Distributed more than 500,000 seedlings in 81 cities,

- Collected more than 70,000 e-mail addresses of environment volunteers and created a database,

- Performed more than 550 plays by the Squirrel Children's Theatre teams. Target figures were 250 performances.

MEEV Project has been presented as the sample for Best Practice from Turkey in the annual meeting of National Reference Centers for Communication (NRCC) of European Environment Agency (EEA) that was held in Copenhagen, Denmark in October 2011. PR activities like MEEV Project in environmental education are important and beneficial but unfortunately number of this kind of projects is not enough.

\section{Conclusion}

Rethinking and revising education from nursery school through university to include a clear 
focus on the development of knowledge, skills, perspectives and values related to environment is important to current and future societies.

Environmental problems need a holistic approach that combines social, political and environmental concerns into community dilemmas. Participatory methods, generally informal, allow people to make connections between social issues and environmental problems. Although the idea of environmental education for adults seems to have widespread support from professionals and the public alike, actual environmental education programs and activities for adults are not always easy to find. PR activities may be useful way to attract attention of adults on the environment.

MEEV Project is a good step for EE in Turkey but achieving the overall objectives set for the project needs a long time. It is also a good example of cooperation of the different governmental and non-governmental organizations and practicing public relations in environmental education.

Hence it is possible to signify that planning of more PR activities in EE should have been beneficial to reach more people. EE should not have been limited by formal education programmes in the schools. PR activities like MEEV Project can contribute to training of people in places which they encounter environmental problems mostly such as city squares, streets, and etc.

\section{References}

Bahar, M. (2000). Information levels of university students about environmental education in Turkey. Presented proceeding in 5th International Ecology and Environment Problems Symposium. 1-3 November. Ankara.

Bamberg, S., \& Moeser. G., (2007). Twenty years after Hines, Hungerford, and Tomera: A new meta-analysis of psycho-social determinants of pro-environmental behaviour. Journal of Environmental Psychology, 27(1), 14-25. http://dx.doi.org/10.1016/j.jenvp.2006.12.002

Bernays, E. (1928). “The New Propagandists” in Propaganda. New York: H. Liverlight.

Clarke, D. A. G., \& Mcphie, J. (2014). Becoming animate in education: Immanent materiality and outdoor learning for sustainability. Journal of Adventure Education and Outdoor Learning, 14(3), 198-216. http://dx.doi.org/10.1080/14729679.2014.919866

Cutlip, S. M., \& Center, A. H. (1955). Effective public relations. NJ: Prenctice Hall.

Environmental Status Report. (2010). General Directorate of Environment Management, Ankara.

Forest Fires Fighting Action Plan. (2012). Genereal Directorate of Forestry, Ankara.

Goldman, D., Schwartz, E., Peled, O., Dunetz, D., Chen, S., \& Gavrieli, Y. (2003). Policy towards environmental education: The place of environmental education and toward a new vision. Position paper, National Counsel for Environmental Quality, Committee for Education.

Grunig, J. E., \& Hunt, T. (1984). Managing Public Relations (6th ed.), Orlando, FL: Harcourt Brace Jovanovich.

Hausbeck, K.W., Milbrath, L.W., \& Enright, S. M. (1992). Environmental knowledge, awareness and concern among 11th-grade students. Journal of Environmental Education, 
24(1), 27-34. http://dx.doi.org/10.1080/00958964.1992.9943493

Hines, J. M., Hungerford, H. R., \& Tomera, A.N. (1986). Analysis and synthesis of research on responsible environmental behavior: A meta-analysis. The Journal of Environmental Education, 18(2), 1-8. http://dx.doi.org/10.1080/00958964.1987.9943482

Huckle, J. (1993). Environmental education: A view from critical theory, In J. Fien (Eds.), Environmental education: A pathway to sustainability (pp. 41-69). Geelong: Deakin University Press.

Hungerford, H. R., \& Volk, T. (1990). Changing learner behavior through environmental education. The Journal of Environmental Education, 21(3), 8-21. http://dx.doi.org/10.1080/00958964.1990.10753743

Intergovermental Conference on Environmental Education, Tbilisi (1977).

Kyburz-Graber, R., Hofer, K., \& Wolfensberger, B. (2006). Studies on a socio-ecological approach to environmental education - a contribution to a critical position in the education for sustainable development discourse. Environmental Education Research, 12(1), 101-114. http://dx.doi.org/10.1080/13504620500527840

Lattimore, D., Baskin, O., \& Heiman, S. (2004). Public relations: The profession and the practice. New York: McGraw-Hill.

Lieberman, G. A., \& Hoody, L. L. (1998). Closing the achievement gap: Using the environment as an integrating context for learning. State Education and Environment Roundtable, Poway, CA.

McCamy, J. L. (1940). Government publicity: Its practice in federal administration. Chicago: The University of Chicago Press.

Ozdemir, O. (2007). A new environment education perspective: Education for sustainable development. Education \& Science, 32(145), 23-38.

Oztas, F., \& Kalipci, E. (2009). Teacher candidates' perception level of environmental pollutant and their risk factors. International Journal of Environmental \& Science Education, 4(2), 185-195.

Palmer, J. A. (1998). Environmental education in the 21st century: Theory, practice, progress, and promise. London: Routledge.

Pieczka, M. (2006). Public Opinion and Public Relations. In M. Pieczka \& J. L'Etang (Eds), Public relations: Critical debates and contemporary practice (pp. 423-432). NJ: Lawrence Erlbaum Associates.

Roth, C. E. (1992). Environmental literacy: Its roots, evolution and directions in the 1990s. Ohio:Columbus.

Seitel, F. P. (2007). The practice of public relations. (10th ed.), Upper Saddle River, NJ: Pearson Prentice Hall.

Smyth, J. C. (2006). Environment and education: a view of a changing scene. Environmental Education Research, 12(3), 247-264. http://dx.doi.org/10.1080/13504620600942642

United Nations Conference on the Human Environment. (1972). Stockholm.

Varinca, K. (2008).. Pressures on water resources related to the climate change. Proceedings of Regional Meetings of 5th World Water Forum, 25-26 September 2008, Artvin, 28-35. 
Wals, A. E. (2014). Convergence between science and environmental education. Science, 344(618), 583-584. http://dx.doi.org/10.1126/science.1250515

Wilke, R. (1995). Environmental literacy and the collage curriculum. EPA Journal, 21(2), 28-30.

\section{Copyright Disclaimer}

Copyright reserved by the author(s).

This article is an open-access article distributed under the terms and conditions of the Creative Commons Attribution license (http://creativecommons.org/licenses/by/3.0/). 